\title{
Prostate Cancer pM1 TNM Finding v6 and v7
}

National Cancer Institute

\section{Source}

National Cancer Institute. Prostate Cancer pM1 TNM Finding v6 and v7. NCI Thesaurus.

Code C48246.

Prostate cancer with distant metastasis. (from AJCC 6th and 7th Eds.) 